\title{
PHYTOCHEMICAL SCREENING AND GASS CROMATOGRAPHY - MASS SPECTROMETER (GC-MS) ANALYSIS ETHANOL EXTRACT OF PURPLE SWEET POTATO (Ipomoea batatas L.)
}

\author{
Surti Kurniasih $^{\left.a^{*}\right)}$, Dina Dyah Saputri ${ }^{a}$ \\ a) Universitas Pakuan, Bogor, Indonesia \\ *) Corresponding Author: kurniasihsurti@yahoo.com
}

Article history: received 08 Juny 2019; revised 17 July 2019; accepted 25 August 2019

\begin{abstract}
Abstrak. Purple sweet potato (Ipomoea batatas L.) leaves are extremely versatile that possesses high value. Sweet potato (Ipomoea batatas L.) leaves have secondary metabolism compounds that used as antibacterial and antifungal. The content of secondary metabolite compounds contained in plants an important role in providing antibacterial and antifungal activity so that this study was conducted to develop the utilization of purple sweet potato leaves through phytochemical screening. Phytochemical screening aims to provide an overview of the class of compounds contained in purple sweet potato leaf plants including of alkaloids, steroidstriterpenoids, saponins, flavonoids, and tannins test. Samples were taken from the local community of Bogor. The extract is made by extracting the simplicia of positive purple sweet potato leaves containing alkaloid, steroids-triterpenoids, saponins, flavonoids, and tannins. Further identification of active compounds was performed by Gass Cromatography-Mass Spectrometer (GC-MS) analysis to detect the active compound contained in purple sweet potato leaf extract more specifically. GC-MS analysis results show several active compounds including: 1.4-Benzenediol (CAS) Hydroquinone, Benzenesulfonic acid 4-hydroxy (CAS), Hexadecanoic acid (CAS) Palmitic acid.
\end{abstract}

Keywords: GC-MS; ipomoea batatas 1.; phytochemical screening

\section{INTRODUCTION}

Flour or amylase is a widely used polysaccharide for the food or medicine industry, comes from plants or tubers from tree yams, sweet potatoes or cereal grains such as corn and wheat [1]. Sweet potato (Ipomoea batatas L.) is a well known plant among the people because it can be found in various regions throughout Indonesia. Purple sweet potato is an alternative food food other than rice, which is a source of vitamins and minerals that are very beneficial to health. Part of purple sweet potato that is widely used as foodstuff is tuber, but it turns out the leaves of sweet potato nutrient content is not inferior to the tuber so it has been widely used as vegetables by the community.

Purple sweet potato is a very familiar plant for us, and the most common are white, purple, yellow or orange sweet potatoes. The advantages of a colorful purple sweetpotato that contains anthocyanin. Antosianin is a secondary metabolite of flavonoids and polyphenols that can act as antioxidants (Ginting [2]).

Research on the content of secondary metabolites in plants has been done and proved to be potential as a biopesticide and there is even a potential as a natural insecticide or bioinsektisida on plant-causing pathogens because secondary metabolite content one of the flavonoid group. Nevertheless, the research on purple sweet potato leaves has not been done so much so that it is necessary to do preliminary research of antifungi activity of purple sweet potato leaf extract to Fusarium Oxysporum growth which is supposed to produce secondary metabolite compound so that it has potential to be developed into biopesticide and can be used as an environmentally friendly alternative pesticide and safe for humans.

\section{RESEARCH METHODS}

Purple sweet potato leaves and stems (Ipomea batatas) are dried for 1-2 days in the oven at $50{ }^{\circ} \mathrm{C}$ for $3-4$ days. Purple sweet potato leaves that have been dried and then mashed by using a blender until it becomes powder and filtered using a filter with a size of 40 mesh. The samples of purple sweet potato were analyzed by using oven method (AOAC [3]). The principle is to evaporate the free $\left(\mathrm{H}_{2} \mathrm{O}\right)$ water molecules present in the sample. Then the sample is weighed until the constant weight is assumed that all the water contained in the sample has been evaporated. The difference in weight before and after drying is the amount of water vaporized.

The preparation of extract using $70 \%$ ethanol solvent. The simplicia is macerated as much as 15 grams with each solvent in the ratio of 1: 10 for 5 days at room temperature. Then the sample is filtered. Each of the filtrate was evaporated with a rotary evaporator at $60^{\circ} \mathrm{C}$. to evaporate and concentrate the extract. The concentrated extract is weighed and the rendement is obtained.

\section{Phytochemical Screening}

Triterpenoid-Steroid test

A total of $10 \mathrm{mg}$ of sample was added with $5 \mathrm{ml}$ of ether, then evaporated in a vaporizer plate. The test solution 
was added with Lieberman-Burchard reagents (acetic acid anhydride and concentrated acetic acid).

Alkaloid test

A total of $10 \mathrm{mg}$ of extract was added with $1 \mathrm{~mL}$ of $2 \mathrm{~N} \mathrm{HCl}$ and $9 \mathrm{~mL}$ of aquades, then heated for $2 \mathrm{~min}$ and cooled. Filtrate is filtered and accommodated. The obtained filtrate is a test solution for Meyer, Wagner and Dragendorf reagents. The presence of alkaloids in the sample is indicated by the formation of white or yellow deposits on the Meyer reagent, brown to black deposits on the Wagner reagent and brown orange precipitate on the Dragendorf reagent.

Saponin test

A total of $10 \mathrm{mg}$ of sample was put into a test tube, then $10 \mathrm{~mL}$ of hot water was then cooled. The test solution was shaken vertically for 10 seconds, then observed for 10 minutes. The formation of a $1-10 \mathrm{~cm}$ high foam indicates the presence of saponins in the sample. In addition 1 drop of $2 \mathrm{~N}$ $\mathrm{HCl}$ of froth is not lost.

Flavonoid test

A total of $10 \mathrm{mg}$ of sample was reacted with $10 \mathrm{~mL}$ of water then heated. The mixture was separated and the filtrate was powdered $\mathrm{Mg}, 1 \mathrm{~mL}$ concentrated $\mathrm{HCl}$ and $1 \mathrm{~mL}$ of amyl alcohol. The positive test is marked by the appearance of color on the amyl alcohol layer.

Tanin test

The test solution was prepared by reacting $10 \mathrm{mg}$ of sample with $50 \mathrm{ml}$ of water, then heated to boiling for 5 minutes and filtrate filtered. A total of $5 \mathrm{ml}$ of test solution was introduced into the test tube, then added a few drops of FeCL3. The formation of violet green color indicates the presence of tannin.

\section{Gass Chromatography - Mass Spectrometer (GC-MS) Analysis}

The purple sweet potato ethanol extract was dissolved with acetone, then injected into a GC-MS device. The GCMS process uses a Phase Rtx-5MS capillary column with a length of $60 \mathrm{~m}$ and a diameter of $0.25 \mathrm{~mm}$. Equipment conditions include: column temperature $50{ }^{\circ} \mathrm{C}$, helium gas, SPL Temperature $280{ }^{\circ} \mathrm{C}$, MS Interface $280{ }^{\circ} \mathrm{C}$, pyrolisis temperature $280^{\circ} \mathrm{C}$, and ion surface $200^{\circ} \mathrm{C}$.

\section{RESULTS AND DISCUSSION}

\section{Sampel preparation}

Leaves of dried sweet potatoes are tested against moisture content. Determination of this moisture aims to determine the durability of simplicia in the storage period. Determination of sample water content by oven method (AOAC [3]). Water content obtained from this research is $6.18 \%$.

The dried sweet potato leaves are tested for moisture content. Determination of water content aims to express the content of substances in plants as percent dry matter and to determine the resistance of a material in storage (Harjadi [4]). Samples with a moisture content of less than $10 \%$ are good samples to store for long periods of time. Good water content is less than $10 \%$ because at this level the sample can be stored for long periods so avoid the contamination caused by bacteria and fungi (Winarno [5]). High water content causes microbes to grow more easily (Naibaho [6]). Reduced moisture content in the sample can facilitate the destruction of the material into powder for the extraction process and also damage to the cell wall during drying will facilitate the removal of compounds in the material (Hernani and Raharjo [7]). Water content obtained in this study is $8 \%$. This indicates that the sweet potato leaf sample has the resistance to be stored for long periods of time.

Sweet potato leaves are extracted with $70 \%$ ethanol solvent. $70 \%$ ethanol extract had a yield of $35.44 \%$. Sweet potato leaf extraction was done by maceration method. This method is chosen because it is simple. Maseration is a suitable method used especially for active compounds contained in sweet potato leaves that are not heat resistant during the extraction process. Maseration is done by soaking the sample into the solvent with a ratio of 1:10 for 5 days while occasionally stirring. The purpose of stirring is that the sample does not settle and the active compound can be dissolved (Nuria [8]).

Ethanol $70 \%$ yields yield of $35.44 \%$ extract. The high rendement of sweet potato extract with $70 \%$ ethanol solvent showed that $70 \%$ ethanol solvent in sweet potato leaf was able to extract many compounds, because the yield of the compound was based on the similarity of polarity properties to the solvent. The number of rendemen counted is over $20 \%$ (Indriani [9]).

\section{Phytochemical screening}

Components contained in ethanol extract $70 \%$ purple sweet potato leaves were analyzed class of compounds with color test test with several reagents for triterpenoids, alkaloids, saponins, flavonoids, and tannins. The results of phytochemical screening of ethanol extract of $70 \%$ purple sweet potato leaves were presented in Table 1 .

Table 1. Results of Phytochemical Screening of Purple Sweet Potato Leaf

\begin{tabular}{|l|l|l|l|}
\hline $\begin{array}{c}\text { Phytochemical } \\
\text { screening }\end{array}$ & \multicolumn{1}{|c|}{ Reaction } & \multicolumn{1}{|c|}{ Result } & Conclusion \\
\hline Triterpenoid & $\begin{array}{l}\text { Liebermann- } \\
\text { burchad }\end{array}$ & $\begin{array}{l}\text { Reddish-brown } \\
\text { colour }\end{array}$ & Positive \\
\hline Steroid & $\begin{array}{l}\text { Liebermann- } \\
\text { burchad }\end{array}$ & Green colour & Positive \\
\hline \multirow{2}{*}{ Alkaloid } & Mayer & White sludge & Positive \\
\cline { 2 - 4 } & Wagner & $\begin{array}{l}\text { Reddish-brown } \\
\text { colour }\end{array}$ & Positive \\
\cline { 2 - 4 } & Dragendroff & Orange colour & Positive \\
\hline Saponin & water $+\mathrm{HCl}$ & Stable foam & Positive \\
\hline Flavonoid & $\mathrm{Mg}+\mathrm{HCl}_{3}$ & Orange colour & Positive \\
\hline Tanin & $\mathrm{FeCl}_{3} 1 \%$ & $\begin{array}{l}\text { Blackish-green } \\
\text { colour }\end{array}$ & Positive \\
\hline
\end{tabular}

\section{Gass Chromatography - Mass Spectrometer Analysis}

The results of Gass Cromatography - Mass Spectrometer (GC-MS) analysis show that in extract of purple sweet potato ethanol (Ipomoea batatas L.) there are several active compounds (Figure 1). 


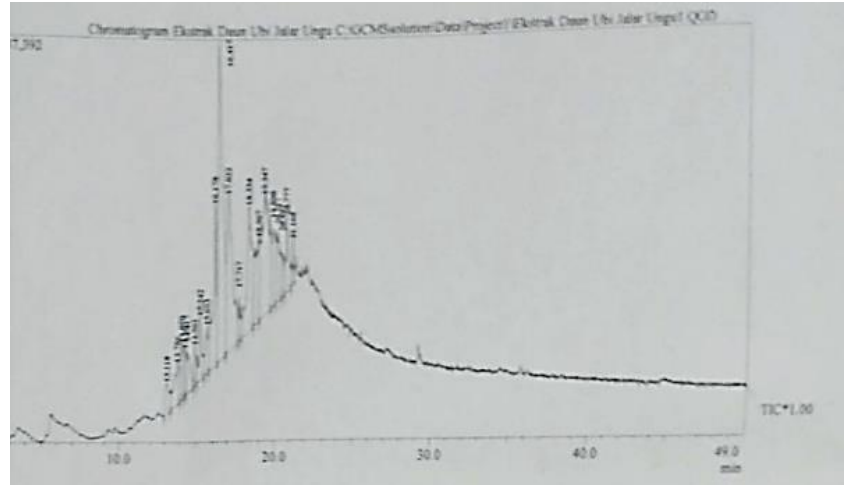

Figure 1. Compounds contained in ethanol extract of purple sweet potato leaves (Ipomoea batatas L.)

The compounds detected in the GC-MS analysis with the highest concentration were 1,4-Benzenediol (CAS) Hydroquinone with a concentration of $19.70 \%$. 1,4Benzenediol (CAS) Hydroquinone is a class of phenol compounds with the chemical formula C6H6O2 (National Chemical Inventories, [10]). In addition to 1,4-Benzenediol (CAS) Hydroquinone, there are other phenol compounds Benzenesulfonic acid, 4-hydroxy- (CAS) with a concentration of $1.85 \%$. Phenol is a bioactive compound that acts as an antibacterial in medicinal plants (Proestos et al.[11]). Phenols and carboxylic acids have antimicrobial activity on Sesame radiatum (Shittu et al. [12]). The content of other secondary metabolite compounds suspected to act as active compounds on ethanol extract of purple sweet potato leaves (Ipomoea batatas L.) is Hexadecanoic acid (CAS) Palmitic acid as much as $2.89 \%$. Hexadecanoic acid includes a palmitic acid group compound. The hexadecanoic acid is a major component of the red algae of $F$. hillebrandii, which has antibiotic potency as antibacterial to Salmonella typhi, Shigella sp., and Enterococcus faecalis (Manilal et al. [13])

\section{CONCLUSION}

The sweet purple sweet potato ethanol extract contains active compounds of alkaloids, flavonoids, tannins, saponins, and triterpenoids. GC-MS analysis results show several active compounds including: 1.4-Benzenediol (CAS) Hydroquinone, Benzenesulfonic acid 4-hydroxy (CAS), Hexadecanoic acid (CAS) Palmitic acid.

\section{REFERENSI}

[1] P. Citroreksoko, A. Taufik, A. Murharini, S. Purawisastra, and Y. Suchyadi, 2012. Kimia Terapan, 1st ed. Jakarta: Universitas Terbuka.

[2] Ginting E, Utomo JS, Yulifianti R, Jusuf M. 2011. Potensi Ubi Jalar Ungu sebagai Pangan Fungsional. Iptek Tanaman Pangan 6(1): 116-138.

[3] AOAC (2005) Official method of Analysis. 18th Edition, Association of Officiating Analytical
Chemists, Washington DC, Method 935.14 and 992.24.

[4] Harjadi, S. S. 1993. Pengantar Agronomi. Gramedia. Jakarta.

[5] Winarno,F,G . 1997. Kimia Pangan dan Gizi. Jakarta: Gramedia Pustaka Utama.

[6] Naibaho FG. 2015. Aktivitas antimikrob dan identifikasi senyawa bioaktif ekstrak bawang batak (Allium chinense G.Don.) [tesis]. Bogor (ID): Institut Pertanian Bogor.

[7] Hernani, Raharjo, M. 2005. Tanaman Berkhasiat Antioksidan. Jakarta : Penebar Swadaya.

[8] Nuria, M.C., A. Faizatun., dan Sumantri. 2009. Uji Antibakteri Ekstrak Etanol Daun Jarak Pagar (Jatropha cuircas L) terhadap Bakteri Staphylococcusaureus ATCC 25923, Escherichiacoli ATCC 25922, dan SalmonellatyphiATCC 1408. Jurnal Ilmu -ilmu Pertanian. 5: 26 -37.

[9] Indriani, Y.H. 2007. Membuat Kompos Secara Kilat. Penerbit PT. Penebar Swadaya.Jakarta.

[10] National Chemical Inventories (NCI), 2007. https://www.cas.org/products/nci-global

[11] Proestos C, Chorianopoulos N, Nychas GJ, Komaitis M. 2005. RPHPLC analysis of the phenolic compounds of plant extracts. Investigation of their antioxidant capacity and antimicrobial activity. $J$ Agric Food Chem. 53:1190-1195.

[12] Shittu LAJ, Bankole MA, Ahmed T, Bankole MN, Shittu RK, Saalu CL, Ashiru OA. 2007. Antibacterial and antifungal activities of essential oils of crude extracts of Sesame radiatum against some common pathogenic microorganisms. Iran J Pharmacol Ther 6:165-170.

[13] Manilal A, Sujith S, Selvin J, Shakir C, Kiran GS. 2009. Antibacterial activity of Falkenbergia hillebrandii (Born) from the Indian coast against human pathogens. International Journal of Experimental Botany. 78:161-166. 